\title{
AUTONOMOUS ARTICULATIONS OF CREATIVE PRACTICES AND RESOURCES MANAGEMENT IN ART PRODUCTION AND EXHIBITION IN RIO DE JANEIRO
}

Alex Frechette
alexluiz@gmail.com
Fluminense Federal University,
Niterói, Rio de Janeiro, Brazil.

\begin{abstract}
This paper presents some strategies on the productive inclusion of visual and literary arts in an attempt to contribute to the debate concerning Creative Economy's relationships against the neoliberal landscape in which the culture market is embedded. For this purpose, some examples of actions taken by Brazilian and foreign artists have initially been used, sensibly shifting towards the social-political context of artivism, until the management of personal experiences was reached.
\end{abstract}

Keywords: Arts; Creative Economy; Artivism.

(eywords: Arts; Creative Economy; Artivism. 


\section{INTRODUCTION}

\section{From market hermeticism to inclusive imagination}

The strategic artistic experiences of inclusive production that encompass the management of resources, and not properly profits, are numerous. This paper is aimed to exemplify some of them, starting with actions taken by certain Brazilian artists in a sampling from the 1970's, passing by aesthetic-political actions and, ultimately, making use of the author's personal artistic experience of producing and propagating his works through social media, independent book publishing and exhibitions in his place. Thus, commending autonomous actions, it is possible to invoke Hakim Bey when he says that you already are the monarch of your own skin - your inviolable longs for being complete only by the love of other monarchs: a dream policy, as urgent as the blue from the sky (2003, p. 5).

The visual arts market is hermetic and it insistently follows the capitalist logic. Hence, it creates an environment that overvalues the surpassing of prices in works from artists that have been historically elected, as if they represented post mortem personal victories. The breaking records in sales value of paintings such as Van Gogh, Basquiat, Dali - just to mention the ones that are best known - a certain media narrative indicates that those sales would be a way to revaluing such artists that, in their time, did not have a proportionate recognition of their abilities. The myth of the wronged hero is sold, albeit "justice never fails", disregarding that the fame process is itself entwined with great and complex business schemes, and that fame in this case translates into the transformation of the artist into a product, as it had already been announced by the "expert duo" composed by the artists Ricardo Basbaum and Alexandre Dacosta, who have distributed pamphlets across Rio de Janeiro streets in 1984, carrying the message "what is success? Success is becoming a product in the consumer society". This work was called "handbill-manifesto".

The expert duo also printed wheat-paste posters between 1981 and 1984 and pasted them in Rio de Janeiro and São Paulo streets with their names, Ricardo Basbaum and Alexandre Dacosta and, underneath such text, they featured only their profession: expert artists. Thereby, what are artists expert in? Why are artists hired? This personal advertisement is connected to the idea that everything could be sold and publicized for such, uncovering the absurd that transforms individuals' own name, face and body into a product destined to be replicated and sold for whomsoever is interested. This happened in a time when visiting museums and galleries was even less frequent, given their fewer numbers in Brazil.

Popularity is interesting for profits even when it is contradictory. A notorious example can be found in the artist Frida Kahlo, openly a communist that is currently lusciously represented by brands that do not seem to be very aligned with Frida's political position, but which accept and glorify her since the replication of her image is profitable. Accordingly, capitalism disregards contradiction when financial profits are at stake.

Rapidly undergoing another example from the international market, Damien Hirst, a conceptual artist, created in 1991 his work named "The Physical Impossibility of Death in the Mind of Someone Living". This artwork concerned a real dead shark in formalin that originally costed British collector Charles Saatchi 50 thousand pounds and was sold in 2004 by 6.5 million pounds to American Steve Cohen. Putting aside any queries, interpretations and critiques over the artistic object, the point is that what is stirred is a certain economic sense, the idea that art is an exacerbated way of wasting money, directed to a segment of the bourgeoisie that is a tiny part of the population, whilst ignoring the fact that these high amounts of resources are related to a deregulated market that makes the same work's price double, triple and multiply as much as possible, depending on the scaling "fame" of the artist. In this way, when art is allied to an excluding market, it is also tied with economic issues that deviate a lot from the daily life of those who harshly need to save their individual day-by-day consumptions. Perhaps for this reason the influence of capillarity of Brazilian Romero Britto in terms of the reproducible consumption platforms is feasible. Albeit being overlooked by great museums, it is adopted by other state and market institutions.

Therefore, digital platforms can work as tools for the democratization of art in the sense of approaching not only the artistic object, but artists themselves. However, it is worth highlighting that the majority of national museums is free of charge or has a specific day in which tickets are not charged. The consumption of museum experience, of experience as an intangible goal, is possible; however, acquiring an artwork, mainly not reproducible as a painting or sculpture is far below something ordinary for most Brazilians. The reproduction of artistic works can be regarded as a good that is subject to valuation and symbolism of gathering the paths and poetics between public and artists so as to reach the possibility of several critique studies and subsequent in-depth analysis. In this sense, such appropriations of breaches and clefts of artistic images' democratization through social media may be regarded as a possible aesthetic-political strategy. 
Brazilian Journal of Operations \& Production Management Volume 15, Número 3, 2018, pp. 396-404

DOI: 10.14488/BJOPM.2018.v15.n3.a6
When Ricardo Basbaum and Alexandre Dacosta were acting as an Expert Duo, they used the means in a process of lowering costs that was falling upon the technologies of that time to perform their works. Just like the Brazilian collaborative movement "3nós3", which started its activities in the 1970's and directly criticized the partitioning of the gallery as an exclusively art-driven venue, past a sort of " $x$ " in gallery's doors at night, as if they were being sealed. They also pasted a poster in the doors of the said galleries stating that "what is inside remains, what is outside expands". The collaborative movement composed by Hudinilson Júnior, Mário Ramiro and Rafael França performed urban actions. One of them consisted of the action of putting black bags over the heads of statues that were placed in the urban environment, in squares and streets, creating a visual strangeness and, at the same time, a certain sense of production of the city, as a transformation of the urbe by acting beings that also build subjective thinking webs in the city. After putting these bags over the statues, as if they were shielding them from the urban violent and sweet daily spectacle, they called newspapers offices claiming to be disgusted residents, in a certain way denouncing themselves so that the press media would unknowingly help them to foster the discussions over those actions, even if, at first, they took place in a media environment of sensationalism and superficiality. Thereafter, the collaborative moment would exhibit their own stories as part of their work, under a process of media re-appropriation and somehow "making it anthropophagic"1, as forebode by Oswald de Andrade in his anthropophagic manifesto that, in outline, stated that it is necessary to swallow the adversary as some Brazilian tribes used to do and recalling the case in which Portuguese bishop Pedro Fernandes Sardinha's was devoured. Eating the opponent's features in a ritualistic way and bringing them inside your own body was the action taken by some indigenous tribes that could be adopted by us. As Oswald said, "only anthropophagy can unite ussocially and economically".

A favorable horizon for the democratic practice, of the predominant thought in the artwork took place through the shift of concepts that the risk fields of Marcel Duchamp's ready-made has opened, triggering other sensibilities and broadening the range of the artist's metaphors. Among Brazilian artists, such attitude of withdrawing an object from its daily life - ready-made, placing it in an environment of artistic exhibition such as a gallery or a museum as Duchamp did with the urinal, which he baptized as "fountain", also had a great impact. In a text, Hélio Oiticica talks about the "new objectivity" that people could recreate, for example, one of his

1 "Anthropophagy" and its derivatives have the same sense as cannibalism. pieces of work, already pointing to the feasibility of the democratization of art's tangible matter, since the principal matter, the matter of reflection was there to be held in many other dimensions, not the "original" work or the fetish of possessing that has passed directly by the artists' hands. "Piracy" would be accepted and even desired. Their penetrable installations, works in which the audience can enter to feel the change of sensations imposed by the color, the stones, the sand, the waters, have been recreated, grounded on the drawings and models of Hélio himself, still remaining as his work, as it is impregnated with the concept in any material that Oiticica's instructions point to.

Art and vehicle have also been explored by Cildo Meirelles as in his series Interventions in ideological circuits, where, for example, he takes advantage of Coke's productive circuit, printing in some returnable bottle, thereby getting back to the factory in order to be filled again with Coke's dark fluid, and then once again to the public, with messages such as "Yankes, go home!" and also instructions on how to make a Molotov cocktail with the own returnable glass bottle, making use of the system of goods flow to turn it into a system of art flow, seizing Coke's popular penetration. Such heritage from Duchamp that has ingeniously and paradoxically overcome the mimesis of the artist as an imitator of nature or creations of others has led to contemporary stance that the aforementioned Hélio's New Objectiveness, and the artists of his generation with Lígia Clarck and Lígia Pape, linked to the performance and to the concept, could also have a breeding ground to develop. It was not by chance that Duchamp himself bought a reproduction of Leonardo da Vinci's Monalisa, the world's most famous painting and painted a mustache over such reproduction, claiming that henceforth it would be a work of his own. The reproducible Monalisa, the Monalisa from little art stores and, hereinafter, Duchamp's Monalisa with a mustache would use the same machinery of image reproduction machines in its production.

Paulo Brusky's resources management can also be a great point to analyze until we get to social media. Brusky remains performing his exhibitions and perhaps even more often today than when he was still a civil servant, which was his main financial source at the time. One of his work series that can be used as an example was performed through insertions into printed newspapers. He used the small ads session, which was free of charge, and spreaded his artistic ideas out by inserting advertisements that initially seemed to sell tangible products, but that actually sold artistic ideas such as a machine that projected dreams on walls. Paulo also used letters he had received in response to such and to other advertisements from people who said to be surprised, curious or wishing for the invention of these imaginary 
products, expressing a direct contact with an audience that would act otherwise, had this proposition been embedded in a gallery or in an art museum. Bursky's autonomy was aligned with his sustainable proposals regarding media penetration. Also performing in a bookstore with the plate "what is art? What is it for?", registered through pictures, Paulo obtained direct interaction, privileged answers from people who were not into the lexicon, the seldom addicting grammar of art critic or even an aesthetic-historical appreciation. He was thereby able to have conversations that far exceeded art issues. As an example, the Brazilian performer Eleonora Fabião one day decided to take two chairs from her kitchen and go to Carioca Square at downtown Rio de Janeiro with a plate, like Brusky, but with the wordings "I talk about any subject". Being fearful in a first moment, Eleonora says that a few minutes after raising the handwritten plate in a piece of cardboard, a person came and they talked for quite some time, situation that repeated many times in various occasions in which Eleonora replayed her performance. If we think that currently even the photographic record can be more feasible than before, Eleonora's performance gains another more humanistic spectrum, given that there are no monetary relationships or selling interests therein, but solely a great curiosity of a human being for another using his own body structure, vital energy and senses for approaching and translating inner worlds. Human exchange is clear and prolific.

\section{ARTIVISM AND THE CITY}

Thus, if before technologies - even under the modernity of the 1970's, 1980's or 1990's in Brazil - linked to cost reduction in the means of broadcasting information also allowed the conceptual expansion of several artists that made writing, fanzines, drawings on walls, dancing, performances, and gesture as a means for producing art that were alien to the hierarchies of a system of production and reproduction of art scenarios, such as art reviews, catalogs, museums, and galleries, where these were privileged locations for visibility, beating on the street as a performance lab and, at the same time, an environment for promoting innumerate aesthetic practices was adopted as a potential paradigm that can approach occupation practices, such as those from the June 2013 Journeys in Brazil, as the slogan "the street is yours, occupy it".

The scaling and violent stifle of the opposing voices jointly with the overwhelming globalization process, however, suggested other actions against moments of economic and social crisis. Artistic actions in such moment, for example, challenged the subordination of an expressive part of the commercially settled cultural production to the neoliberal thinking, which ended up as- suring the urgency for questioning these practices. This query happened at that time among artistic collaborative movements in the city of Rio de Janeiro, such as "Focupação", which performed a photography action and exhibition with the purpose of changing the city and bringing another point of view over the demonstrations from 2013, criminalized on a daily basis, deploying pictures and drawings that were critic of this vision in big-sized "lambe-lambe" prints on city walls. In that occasion, "Ocupa Lapa" also emerged as a horizontal collaborative movement promoting some editions at Cardeal Câmara Square in front of the Lapa Arches, initially condemning the police repression on June 2013 protesters and fostering public debates that were called "facestreet", art exhibitions, musical performances, performers, circus artists, theater sketches and later breakfasts with homeless people in the street where Cruz Vermelha Square is located. In these latter two events, the author of this paper participated artistically with a series of portraits. These pieces were painted with red and black ink and they portrayed people who have suffered violence during the protests, usually by violent police repression. The work was exposed on the square's ground, occupying a great circle, exchanging visuality at eye level, as art objects are usually exposed, with the purpose of settling a certain reverence to those images, since it was necessary to stoop down in order to read the stories explaining why such figures were there. Each of the 55 images of painted faces was accompanied by accounts of the aggressions suffered by those who had been portrayed.

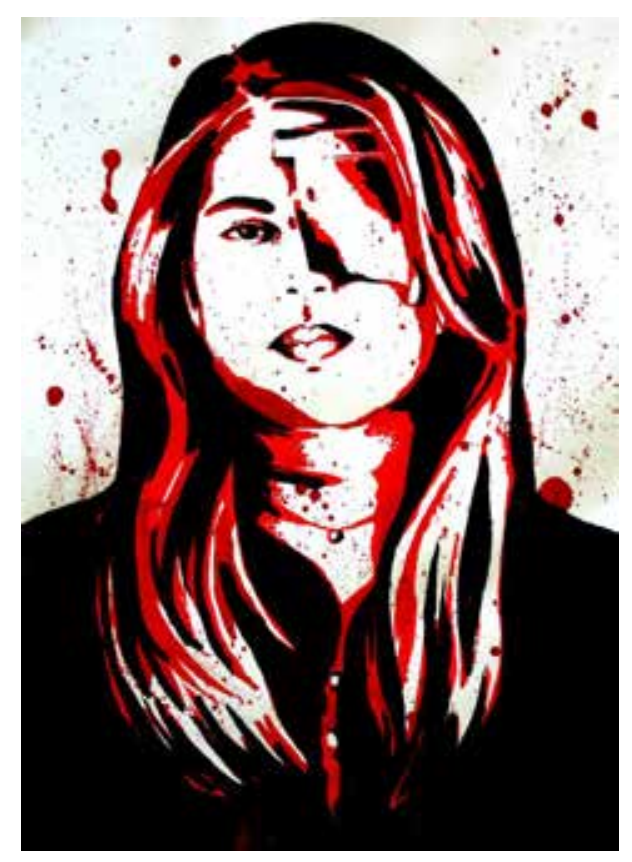

Figure 1. Daily Demonstrations: portrait of Renata da Paz, who lost an eye during June 2013 Journeys

(Alex Frechette Personal Archives) 


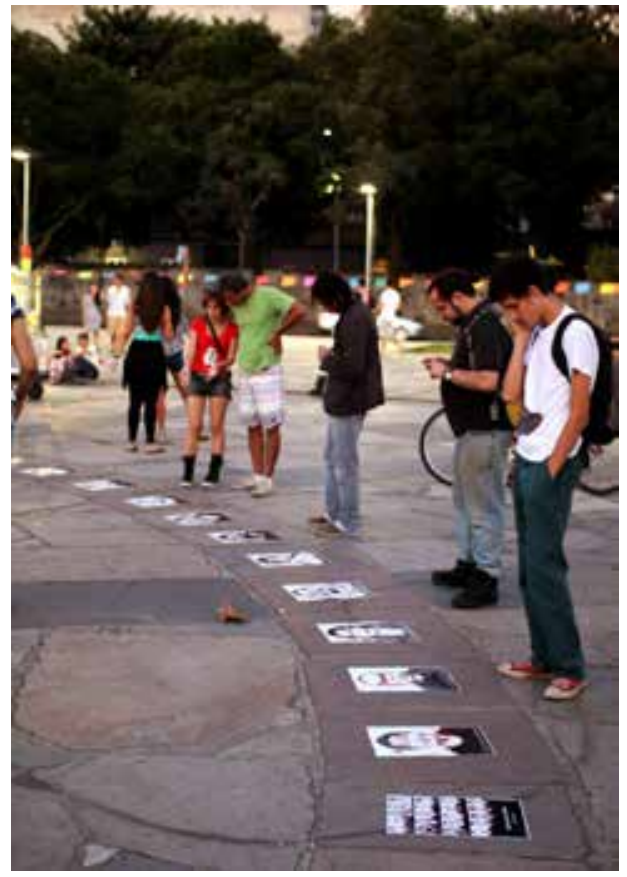

Figure 2. Daily Demonstrations: record of the exhibit in Ocupa Lapa in September, 2013

(Photo: Guidi Vieira)

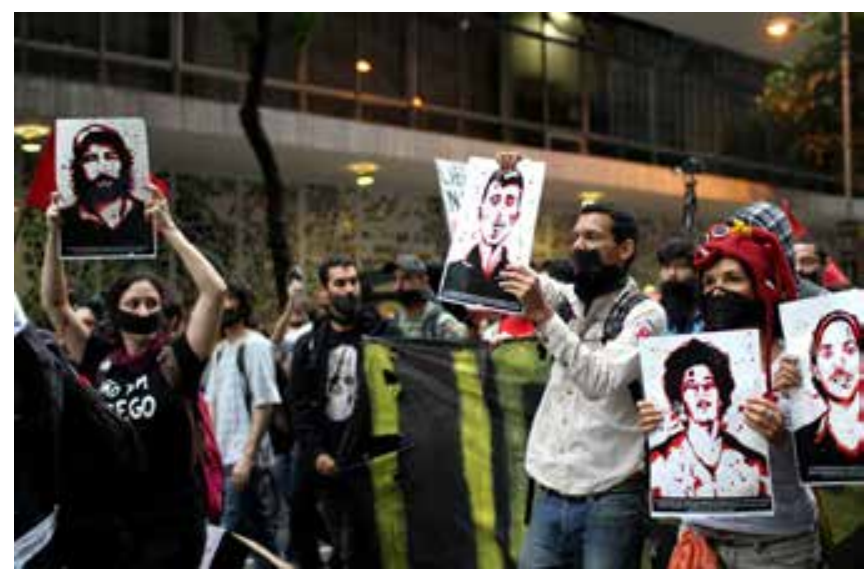

Figure 3. Daily Demonstrations: record of the "Cry for Freedom" act in October, 2013

(Photo: Guidi Vieira)

The Daily Demonstrations ("Manifestações Diárias" in Portuguese) exhibition also shifted towards protests such as "cry for freedom", whose proposal was to have hundreds of people altogether occupying and walking through Rio Branco Avenue, Rio de Janeiro downtown, in silence. Protesters have used clothes covering their mouths in order to denounce the silencing process to which they had been subjected to. Many of them were wielding the paintings from the series as a form of denunciation against those rights violations. The occupation of the public space had occurred not only in the sense of camping, but rather it was an ever enlarging concept since it disjointed the axis of belonging to the city as a possibility of an enduring and autonomous interference. Hence, this author has painted sets of tiles with sentences extracted from the Brazilian Constitution that referred to social rights and has fixed them in many locations of the city. He has performed this in a handcrafted manner, thus referring to a baroque aesthetic in the sense of provoking a dubious feeling regarding their historic presence in terms of institutional legitimacy. This way, with the World Cup event, a series of works that were classified as reinterpretation, in which the technique of the original artist was emulated, manipulating the works of great painting icons so as to embed them into a contemporary Brazilian ambiance, have been developed. The idea was to pictorially portray facts that deserved attention due to their character of rights violation associated with the moment of 2014 World Football Cup. There have been performed reinterpretations of Pablo Picasso, Jean Michel Basquiat, Francisco Goya, Andy Warhol, Hélio Oiticica, Vincent Van Gogh, Tarsila do Amaral, Keith Haring, Romero Britto, René Magritte, Banksy, Marc Chagall, Ernst Kirchner, Edvard Munch, Roy Lichtenstein, Henri Matisse, and Egon Schiele. These personal examples come across with the protests in the sense of "Temporary Autonomous Zones" (BEY, 1985) that are born under an interstitial pathway in the margins of capitalism, in the folds and fractures of the bourgeois democrat system, in web counterflows and in its piracy (RAPOSO, 2016, p.83).

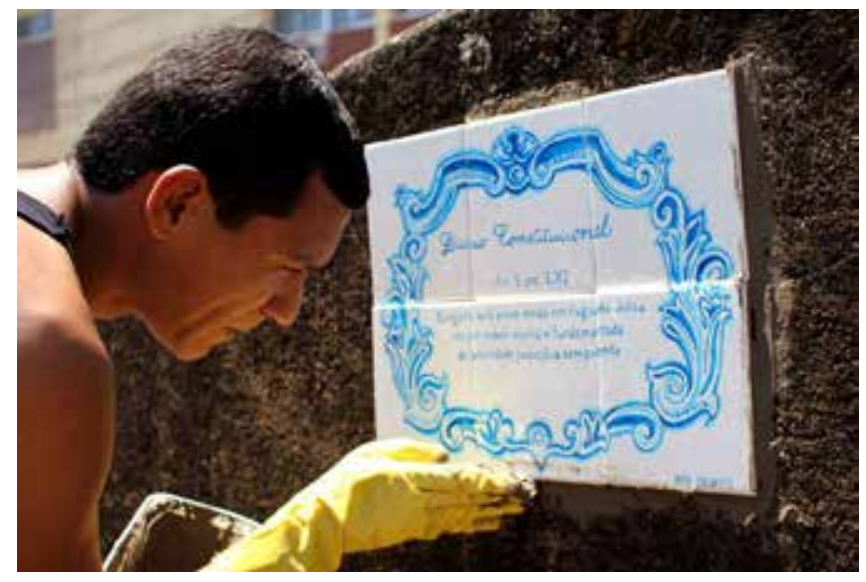

Figure 4. Constitutional Law: record of tiles' application in Santa Teresa, March 2014 (Photo: Guidi Vieira) 


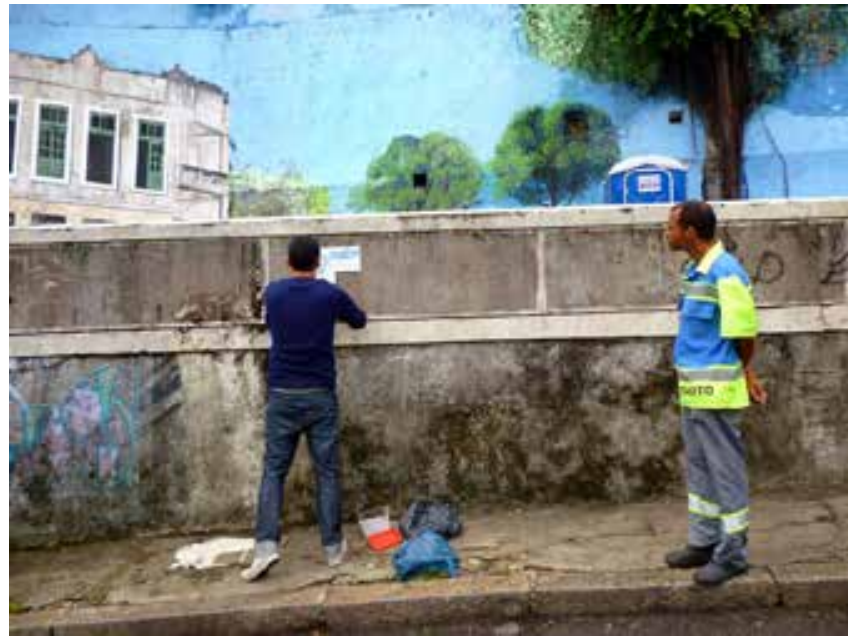

Figure 5. Constitutional Law: record of the tiles application in Santa Teresa, April 2014

(Photo: Guidi Vieira)

The artistic collaborative movement Projetação also took part in the occupation of public spaces by ingeniously using light projectors. They projected images and watchwords on "untouchable" buildings, putting their images and speeches under a big format, somehow broadening the exposure of the demonstrators' agenda. With an electric scheme that enabled to carry a regular projector and to charge it in a car battery, Projetação also made use of a bicycle and, sometimes, of a motorcycle to move these images and their places of projection, deploying inventiveness to slip by the group's budget constraints. Rio de Janeiro's carnival in 2014 also entered the agenda of a challenging artistic occupation through a group called "Tá tudo errado" ("Everything is wrong") that reinterpreted old popular Carnival songs, but criticized the political landscape of the concerned year.

The art that questions economic hegemonic model also takes place under the denomination of artivism that would be a junction of art and activism. Claiming art to be a source of openness to citizenship, as a tool of change in ways of life and as a producer of new axis of combative reflection, in a certain way, leads to the struggle to make individualities to become social. This form of claiming to secure an economically inclusive and humanistic view against the overwhelming economic dimension of the city-good as a space exclusively devoted to consumption connects to the proposal of a diversity encompassing management skills of social interest, working as a focal point between citizenship and political participation, using aesthetic and symbolic strategies. In regard to the conjunction between arts and politics, anthropologist Rui Mourão states that "both affirm themselves according to a praxis that is both idealist and idealized, creating representations that set out the exterior reverberations of what they effectively create in their public exhibition" (MOURÃO, 2015, p. 54). The term artivism appeared in the year of 2003 in Brazil in the article by the art critic and journalist Juliana Monachesi, in the newspaper Folha de São Paulo, whose headline was "The Explosion of $A(r)$ ctivism" ${ }^{\prime 2}$. In a first moment, the said denomination caused rejection among the engaged artists of that time, since it could mean an immobility of actions and an acceptance of the proposal of a hegemonic media. For the anthropologist Paulo Raposo, "Artivism is a conceptual neologism of an unstable consensus either in the social sciences fields or in the arts field" (RAPOSO, 2015, p. 5). Nonetheless, the activism in June Journeys seem to re-appropriate such terminology in a way that is not very problematic. "In this scenario, the emergence of the term arctivism, as an analytical category, marks a political and theoretical interest" (DI GIOVANNI, 2015, p. 3).

Paulo Raposo, who coordinated a course in performance at Fluminense Federal University (UFF) in November 2014, also related to the conflictual political standpoint or June 2013 Journeys and others associated to the Free Pass Movement ("Movimento Passe Livre" in Portuguese), writes about those actions by approaching them to the artivism concept: "artivist actions are multiple: carnival or theatrical celebrations in public space, creation of actions in social media at the internet, stimulus to civil disobedience, piracy on the internet, creation of alternative media, occupations, among many others (RAPOSO, 2016, p. 83). Therefore, plastic creativeness and the attention granted to the aesthetic dimension assume an increasing importance, leading to an "experimental and disruptive function" (DI GIOVANNI, 2015, p. 6) in the new ways of mobilization. In the Olympic Games, movements such as "Ocupa Minc", which occupied several headquarters of the Ministry of Culture across Brazil, including Rio de Janeiro's, due to the threat of dissolution of such Ministry, promoted debates and aesthetic actions whose theme was the queries surrounding these games. The same occurred later in the occupation called "Ocupa Canecão", where artists, cultural professionals and the organized civil society cohabited in that space, sleeping, feeding and managing resources in working groups (WGs), that moved and redistributed food donations and workforce, but also the dynamism of the disclosure of these actions on the internet through photos, videos and militant texts.

In that sense of subverting the uses of spaces alike, the movement "Ocupa Câmara" remained for 67 days at Cinelândia Square, in Rio de Janeiro downtown, in front of the City Council, where protests against a parliamentary inquiry committee, almost entirely composed by city councilors belonging to the government basis that would be entitled of investigating the profits of public transportation in a mild or nonexistent opposition. Therein, they have also promoted art actions such as the "burial" of government-based coun-

2 Originally "A Explosão do A(r)tivismo". 
Brazilian Journal of Operations \& Production Management

Volume 15, Número 3, 2018, pp. 396-404

DOI: 10.14488/BJOPM.2018.v15.n3.a6 cilors, painting the concrete blocks placed at the square, known as "gelo baiano", painting them as graves in order to hinder the transit of vehicles. The group stood there, bearing themselves through combined strength until their tents and tarpaulins got removed by the City Guard. The plurality of agendas was a way of subverting the dominant logic as well, in order to create a heterotopia (FOUCAULT, 1967), that is, to subject spaces in such a way that they function under non-hegemonic conditions where the rebellion of speeches and bodies is possible. Regarding the participation in the city management, in 2013 the self-denominated collaborative movement "Ocupa Cabral" defied the elitist structures of Leblon, a neighborhood in Rio de Janeiro, when it anchored a tent in front of the building of former governor Sérgio Cabral, in protest against his excluding administrations. Several groups have promoted articulations in Rio de Janeiro inspired by international riots, such as the Anonymous group, which organized protest and hacker attacks against the governmental website, besides those who practiced the Black Block tactic, which, in a nutshell, aims at attacking what their participants deem as symbols of capitalism, as for example, banks and big companies. The articulation also gained international grounds with the important creation of the World Cup and Olympic Games Popular Committees, which has produced an extensive and highly relevant counter-narrative and sustainable material.

Philosopher Jacques Rancière states that "the resistance of the work is not the relief that arts provide to politics. It is not the imitation of anticipation of politics by arts, but properly the identity of both. Art is political" (RANCIÈRE, 2017). By that statement, he enables the sense of historical restructuring of artistic thought as automation processes and multiple possibilities to grow hard, position that as from 2013 has encountered ground in Brazil. In regard to the contemporaneity of the theme, Gilson Motta reaffirms that "the project of social reform through political action has also become an artistic ideology, either by architectural or urban projects, or by artistic vanguard, especially futurism, or by situationist international. All the manifestations mentioned above would be embedded into a project of transformation of culture, mentality, and individual and social conditions of life" (MOTA, 2012, p. 6).

Hence, the non-normatization connected to political and artistic interests links to the management of resources that are close to the artist's adventure, of his stance against the processes of life entwining that currently met media tools for artistic propagation in social media that corresponds to one of the largest numbers of web traffic. That was when, as from 2010, the author started using that vehicle to propagate his artistic production and related projects. Therefore, facebook has become an expository space, a 24 hours gallery, where works did not necessarily have to be on sale, or even to have a quantitative limit. The limit was much more held back in its dimensions, thus getting reduced to the small sampling of the social media's time line that, at most, would expand within the size of the computer screen of each person of the audience.

\section{PERSONAL EXPERIENCES OF ARTISTIC AUTONOMY}

Those big changes in the transformations of media and their inherent dynamics of communication, where the possibility in which all of us become media broadcasters, as it had been foreseen when it was said that, in the future, everyone would have their 15 minutes of fame, has enabled not only the reinforcement of actions and the acclamation of specific groups, as occurred in 2013 through Facebook and also through YouTube videos, Instagram photos and its resource, the stories, where an image lasts 24 hours and there are no likes or apparent comments. Through these resources, not only the author, but a range of artists that did not have the possibility of such a broad publicizing has got hold of these means, as the Occupy movements, but this time enlarging the concept and occupying these media.

As another strategy for the management and disclosure of artistic material, the author has turned to independent book publishing, which is also a way of taking possession of this alleged hierarchy that still grants paper, that is, the document aspect of the printed word over the one said, and as a penetration of these articulation arrangements into an emancipatory artistic practice. My experience with fanzines production has already started on the internet, in 2005, because of the practice of proliferating ideas in paper by using photocopies. The author has spent two years producing a fanzine that was initially called HUMzine, and then HUMEletrônico, due to its operation in an electronic platform. Such fanzine had four printed editions in a tabloid format and it has reached a print run of more than three thousand books that were distributed for free in culture venues and which were maintained through small advertisers, such as antiquarians and tattoo studios that helped addressing the printing costs. The other steps of the work were divided among three people that took care of writing, editing and formatting the eight pages tabloid. This experience allowed the independent publishing of books due to the cost reduction of that service.

Usually, the experience with books was divided into two steps. The first one related to producing the text and publishing chapter by chapter in a blog, and the second one referred to the organization of the publication under a physical printed format. It was thereby noted that the entire material process of organization, publishing, recording the work and promoting it added impetus to such activities. Then there was the opportunity of publishing, since 2012, eight books that have been denominated the dia- 
ries. In the same way as the artistic works, the diary works that were performed on an everyday basis were baptized that way. The first to be published was the Diary in Niterói, where the author photographed and wrote about the places that marked his childhood in the city through sixty testimonies that corresponded to memories from sixty places. A release was performed in the city's public library where the commercialization was not bureaucratic nor had formal requirements. That was made possible due to the democratic character of libraries as a public space with social vocation. The second release was called Tales Diary, in 2013 , in which daily writing was also used. The author produced sixty tales that had been gathered by him in such publication. This time, living in the city of Rio de Janeiro, the launch was performed by the author at São Salvador Square, in the neighborhood of Laranjeiras. Following the series, came Class Diary, which was about the author's experiences as a newcomer arts teacher in a public school in Rio de Janeiro, composed by tales that he wrote in 2011 and released in 2014 in that same square. The Readings Diary talked about the 40 books that he read and wrote about in 2014. This time, he made a first release in a small bookstore in Santa Teresa, seeking to highlight the union of small producers. Mr. Frechette has also made a Scattered Poetry Diary, released in 2015 in an event that occurred in his place, thus in a certain way radicalizing the disconnection from a productive chain, as he did with the book Affections Diary on the daily scenes that affected him for 2 months. The Diary in Progress, about June 2013 Journeys and his insertion in such context was made through a partnership with a publisher, Circuito, which is devoted to the production of art books. This partnership enabled a distribution through the main platforms for book selling in the country, such as Americanas.com and Submarino, and also abroad, as Amazon, besides the presence in physical bookstores. The Diary to Discolor was made of drawings of difficult moments of the Brazilian history, referring to coloring books that were on the rise in 2015. The latter was also published by Circuito. Only one release has been made in a big bookstore that was somehow centered on a sales projection that deterred the emancipatory aspect, lost in market bureaucracies.

Another action that aimed at popularizing and granting access to arts was the Free Art Fair. Taking into account that the art market is prohibitive for a great part of the population and that the acquisition of this kind of good is connected to instances of social consecration, this fair has been promoted by capturing the notion of popular fair with art fairs that, for example, are found in great economic centers, where there is financial surplus and, therefore, acquiring art means acquiring luxury goods. The idea behind the Free Art Fair was to extend the possibility of obtaining artistic works praising generosity and delivery to the extreme, not expecting to have anything back. Any artist could give whatever he wanted, or nothing, and also take anything, or nothing, as in the example of the Free Gratitude Fairs, where the governing idea was that the scarcity of products in the world was an illusion. The fair was open to anyone who wanted to join it. There were no rules in regard to the quantity or format of the works and much less about their acquisition. Visual artists could give originals or copies of their woks, musicians could make a live performance or donate CDs, writers could donate signed books or manuscripts, performers could donate their performances - everything that could be deemed as an artistic product could be donated and received. While habitually dealing with a certain general incomprehension of the intersubjective values of his work, the artist is in lockstep with his time and social universe. The Free Art Fair would not place such producer on the market, but would rather discuss it, its neoliberal nature and its conflict with the artist's autonomy. In this way, the fair that was held in the square of the Fátima neighborhood in Rio de Janeiro received many donations and also approached the public that could obtain an art work free of any charge.

As a last example of these personal management resources in the author's artistic acting in a specific process, he mentions the exhibits that have been promoted by him in his own house, in the neighborhood of Santa Teresa. Without any paid tickets or restrictive ways of access, he has made two exhibitions, one in 2015 and another in 2016, showing his production until that time. Removing the place's furniture, several spaces of the house have been used, including rooms, kitchen, and toilette. All of them became expository spaces. For example, a series was exhibited on the wall of the anteroom. On the other wall, there was another series. This way the works found their spaces. Ten stained glasses from a series were exhibited on the window, taking advantage of its support and luminosity for a better exposition of these objects. On a table, painted vases, redesigned matrioska dolls, and tiles were exposed. In the TV, tablets and computer screens, many pictures and videos were played intermittently. In one of the rooms that had been kept dark, some videos were projected in loop as well as a candle lamp with the names of all professors that the author has had until such moment, and which reflected on a corner of the wall. In the room, together with the books at the bookcase, the author's books series were exposed along with notebooks from the School Diary that concerned portraits made with ballpoint pen from kids that had been his art students in a city school. In the kitchen, he exhibited his series of dishes hanging on the walls, which came from the so-called series "do not spit on the dish you eat in" with scenes of civil resistance painted in such supports. In the toilette, a series of painted buckets, from the series "buckets to kick" portrayed condemnable actions of professional politicians of the Brazilian scene. In these actions, guests brought food and shared them with the others as part of a sustainable and prosperous economic policy. 
Brazilian Journal of Operations \& Production Management

Volume 15, Número 3, 2018, pp. 396-404

DOI: 10.14488/BJOPM.2018.v15.n3.a6

\section{FINAL REMARKS}

The attempt to create a feasible and changing policy for the creative economy in the city that includes the points of art production that are themselves passed by other knowledge fields and of action, such as politics that is embedded in artivism, set forth strategies of deepening and utter comprehension of a struggle against the coercive power and form normative principles for an institutional policy that devalues the culture field. In a time of high competitiveness guided by the logic of goods accumulation, governed by market, consumption and spectacle laws, where ephemerality makes common cause with the exacerbated consumption of sensation, the debate over the creative economy in the artistic domain at the current stage of globalization and technological development may be analyzed from the perspective of the productive contradictions.

Therefore, art assumes an essence that proposes new imageries before an unequal society in which the demand for equitable social opportunities that satisfy human needs and desires is indispensable. Likewise, these demands relate to the valuation of expression and freedom to criticize, fostering advancements that may join the system of culture codes that expand human repertoire towards the sense of belonging and appropriateness of contestation.

\section{REFERENCES}

Andrade, O. (1928), Manifesto antropófago, Revista de Antropofagia, Ano I, No. I.

Basbaum, R. (2013), Manual do artista-etc, Beco do Azougue, Rio de Janeiro.

Bey, H. (2003), Caos: terrorismo poético e outros crimes exemplares, Conrad, São Paulo, disponível em: http://www. imagomundi.com.br/cultura/caos.pdf (acesso em 16 jul. 2018).

Bey, H. (2011), TAZ - Zona Autônoma Temporária, Conrad, São Paulo.
Centella, O. (2013), Del artivismo como acción estratégica de nuevas narrativas artístico-políticas, Calle14, Vol. 10, No. 15.

Coletivo 28 de maio (2015), O que é uma ação estético-política, Rio de Janeiro, Grupo de Pesquisa Práticas Estético-Políticas na Arte Contemporânea, vídeo (17 min), disponível em: https://www.facebook. com/397266677145068/videos/417925865079149/ (acesso em 15 jul. 2018).

Di Giovanni, J. R. (2015), Artes de abrir espaço. Apontamentos para a análise de práticas em trânsito entre arte e ativismo, Cadernos de Arte e Antropologia, Vol. 4, No. 2.

Fornaciari, C. G. (2016), Junho 2013: Arte e política em performances do corpo social, Pitágoras 500, 10 ed.

Motta, G. (2012), Micro-utopias urbanas: "o banquete dos heróis" pelo coletivo de performance heróis do cotidiano, Revista Ecos, Vol. 12, No. 1.

Mourão, R. (2015), Performances artivistas: incorporação duma estética de dissensão numa ética de resistência, Cadernos de Arte e Antropologia, Vol. 4, No. 2.

Provasi, B. (2016), Atos como Performance na Ocupação do Espaço Urbano: contra um modelo de cidade para os megaeventos, Revista Brasileira de Estudos da Presença, Vol. 6, No. 3.

Rancière, J. (2007), Será que a arte resiste a alguma coisa?, in Lins, Daniel (org.), Nietzsche, Deleuze, arte e resistência, Fortaleza, Forense Universitária.

Raposo, P. (2015), "Artivismo": articulando dissidências, criando insurgências, Cadernos de Arte e Antropologia, Vol. 4, No. 2.

Raposo, P. (2016), A "revolta das barcas": sobre silenciamento performativo e imaterialidade do protesto na (in)visibilidade contemporânea das periferias urbanas, Giz-gesto, imagem e som, Vol. 1, No. 1.

Szaniecki, B. P. (2014), Uma política cultural para as práticas criativas, Lugar Comum: estudos de mídia, cultura e democracia, No. 35-36.

Received: 09 Dec 2017

Approved: 11 Jun 2018

DOI: 10.14488/BJOPM.2018.v15.n3.a6

How to cite: Frechette, A. (2018), "Autonomous articulations of creative practices and resources management in art production and exhibition in Rio de Janeiro", Brazilian Journal of Operations \& Production Management, Vol. 15, No. 3, pp. 396-404, available from: https://bjopm.emnuvens.com.br/bjopm/article/view/418 (access year month day). 